\title{
A HOMESTEADING TIME LINE
}

I 854 Henry David Thoreau's Walden is published.

I 872 John Burroughs leaves Washington, DC, to take up a life of farming and writing in West Park, New York.

I 896 John Burroughs completes the building of his cabin Slabsides and begins living there annually from March to December.

I 905 Scott Nearing builds his first cabin and grows his first organic garden at the single-tax community of Arden, Delaware.

I 907 Bolton Hall publishes Three Acres and Liberty; in I 908 Hall publishes A Little Land and a Living, foreword by Ralph Borsodi's father, William Borsodi.

I 920 Ralph Borsodi and his family leave New York City and establish their first homestead in Rockland County, New York.

I 929 Ralph Borsodi publishes This Ugly Civilization.

I 932 Helen and Scott Nearing purchase their first Vermont homestead, making it their primary residence in 1935.

I 934-35 The School of Living starts up in Suffern, New York, becoming fully established in 1936.

I 938 Henry Tetlow publishes We Farm for a Hobby and Make It Pay.

I 942 Louis Dickinson Rich publishes We Took to the Woods. 
I 944 Carolyn and Ed Robinson publish The Have More Plan, based on their homesteading experiment in Norwalk, Connecticut, begun in 1942 .

I 945 Bradford and Vena Angier read Walden and leave Boston for a life in British Columbia, publishing At Home in the Woods in I 95 I .

I 948 Louis Bromfield publishes Malabar Farm.

I 949 Aldo Leopold publishes A Sand County Almanac.

I 952 Following a shanty boat trip down the Ohio and Mississippi rivers that began in I 943 and lasted eight years, Harlan and Anna Hubbard build a house in Payne Hollow along the Ohio River in Kentucky.

I 954 Helen and Scott Nearing's Living the Good Life is self-published.

I 964 Wendell Berry leaves New York City and reinhabits the LongLegged House part-time while teaching at the University of Kentucky.

I 968 The members of Total Loss Farm settle in Vermont, publishing their collected writings in Home Comfort in I 973.

I 970 The Mother Earth News is launched. Living the Good Life is republished.

I 973 Gene Logsdon publishes Homesteading: How to Find Independence on the Land, to be followed by a series of homesteading books.

I 974 Payne Hollow, by Harlan Hubbard, is published.

I 970 S Helen and Scott Nearing build their last stone house in Maine, when Scott is in his nineties and Helen is in her seventies.

I 983 Scott Nearing dies at age one hundred.

I 987 Wendell Berry publishes Home Economics.

I 995 Helen Nearing dies at age ninety-one. The Good Life Center is established to preserve the Nearings' legacy and promote sustainable living.

2003 William Coperthwaite publishes A Handmade Life. 